\title{
Оптические и электрические свойства диодных структур на базе пористого кремния с эрбием
}

\author{
Н.В. Латухина ${ }^{1)}$, И.М. Жильцов ${ }^{1)}$, М.В. Степихова ${ }^{2)}$ \\ ${ }^{1}$ Самарский национальный исследовательский университет им.академика С.П. Королева, Самара, \\ 443086, Московское шоссе, 34 \\ ${ }^{2}$ ИФМ РАН Нижний Новгород \\ тел:+7 (846)334-5455, факс:+7 (846) 334-5455, эл. почта: ivanzp45wm@yandex.ru
}

DOI 10.34077/RCSP2019-167

Интерес к пористому кремнию как материалу оптоэлектроники связан в первую очередь с большой площадью его поверхности и наличием наноразмерных кристаллов в его порах, что делаем его пригодным к использованию в люминесцентных структурах. $\mathrm{C}$ переходом от монокристаллического кремния к системам нанокристаллического кремния (nc-Si) с ионами $\mathrm{Er}^{3+}$, являющегося редкоземельным элементом, возможно создание эффективных люминесцентных структур, интегрированных в кремниевую оптоэлектронику, что позволит повысить быстродействие, плотность записи информации, помехозащищенность и другие параметры электронных схем на кремниевой подложке. Такие структуры имеют хорошие люминесцентные свойства в ближней ИКобласти спектра при комнатной температуре [1].

В настоящей работе было проведено исследование полупроводниковых диодных структур с пористым слоем, легированным эрбием [2]. Пористый слой создавался на текстурированной и шлифованной поверхностях монокристаллических пластин кремния электролитическим травлением и насыщался спиртовым раствором азотнокислого эрбия, следующим этапом проводилась диффузия эрбия при $900^{\circ} \mathrm{C}$ в течение часа, после остывания образцов снимался окисный слой диффузанта. Последующей за диффузией эрбия была диффузия фосфора при тех же условиях. Завершающим этапом наносились контакты из AL Исследования включали изучение структуры и состава образцов на растровом электронном микроскопе, измерение вольт-амперных характеристик и спектров фотолюминесценции в ближней ИК-области.

Образцы показали хорошую диодную структуру и люминесцентные характеристики с максимумом на длине волны 1,55 мкм при комнатной температуре.

\section{Лuтература}

[1] Кашкаров П.К., Каменев Б.В., Лисаченко М.Г. Эффективная люминесценция ионов эрбия в системах кремниевых нанокристаллов//ФТТ. 2004. Т. 46-В.1. - С. 105-109

[2] Кирсанов, Н. Ю. и др. Влияние параметров технологического процесса на свойства люминесцентных структур на базе пористого кремния, допированного эрбием / Н. Ю. Кирсанов, Н. В. Латухина, М. В. Степихова, Э. Х. Хамзин // XIV Всероссийский молодежный Самарский конкурсконференция научныхработ по оптике и лазерной физике: сборник трудов конференции, 8-12 ноября 2016 г.).- Москва: Федеральное государственное бюджетное учреждение науки Физический институт им. П.Н. Лебедева Российской академии наук, 2016. - 506 с. - с.247-252. 